\title{
Serological survey of Babesia bovis, Babesia bigemina, and Anaplasma marginale antibodies in cattle from the semi-arid region of the state of Bahia, Brazil, by enzyme-linked immunosorbent assays
}

\author{
Silvia L Barros*, Claudio R Madruga/+ , Flabio R Araújo, Carlos F Menk*, \\ Maria Angela O de Almeida*, Elaine PS Melo, Raul H Kessler
}

\author{
Embrapa Gado de Corte, Área de Sanidade Animal, Br 262, Km 4, Caixa Postal 154, 72002-970 Campo Grande, MS, Brasil \\ *Departamento de Patologia e Clínica Veterinária, Escola de Medicina Veterinária, Universidade Federal da Bahia, \\ Salvador, BA, Brasil
}

The objectives of this work were to determine the prevalence of Babesia bovis, Babesia bigemina, and Anaplasma marginale detecting antibodies in cattle raised in the semi-arid region of the state of Bahia, Brazil, through indirect enzyme-linked immunosorbent assays (ELISA) and to compare the performances of indirect enzyme-linked immunosorbent assays with crude (I-ELISA-CrAnaAg) and recombinant major surface protein-5 (I-ELISA-MSP-5Ag), as antigens to detect antibodies against A. marginale. An stable enzootic area was found in Senhor do Bonfim and Euclides da Cunha for B. bovis that showed 86 and $95.5 \%$ of prevalence, respectively, and for $\mathrm{B}$. bigemina with 90.8 and $91.3 \%$. On the other hand, Uauá and Juazeiro were characterized as enzootically unstable areas, since prevalences were: $\mathrm{B}$. bovis - 63.7 and $56.4 \%$ and $\mathrm{B}$. bigemina -53 and $54.8 \%$, respectively. The prevalence of $\mathrm{A}$. marginale in the four municipalities was above 97\% with I-ELISA-CrAnaAg and 94.8\% with I-ELISA-MSP-5Ag which is an indication of stable enzootic condition for the rickettsia. The I-ELISA-CrAnaAg and I-ELISA-MSP-5Ag showed a highly significant association $(r=0.977)$, which means that both ELISA tests are suitable for epidemiological studies of A. marginale.

Key words: Anaplasma marginale - Babesia bovis - Babesia bigemina - ELISA - prevalence - semi-arid - Brazil

Bovine babesiosis, caused by hemoprotozoans Babesia bovis and Babesia bigemina, as well as anaplasmosis, whose etiological agent is the intraerythrocitic rickettsia Anaplasma marginale, are responsible for important economical losses in the cattle industry of tropical and subtropical areas of the world. In Brazil, the annual losses caused by these hemoparasites were recently re-estimated in US\$ 500 million (Grisi et al. 2002).

The economical impact is a consequence of direct losses, such as mortality, reduction in meat and milk yield, and indirect ones with the application of control measures. The most relevant pathogenicity aspect of these hemoparasites is the marked anemia that leads to high percentage of mortality in non-immune cattle herds (Kessler \& Schenk 1998).

In the Brazilian territory, both species of Babesia and A. marginale are highly prevalent in the majority of the regions (Souza et al. 2000, Madruga et al. 2001). However, some microregions of the northeastern and southern regions are exceptions, because they are endemically unstable (Oliveira et al. 1992). In the Brazilian northeastern states, there are large areas with semi-arid climate, which are unsuitable for development of Boophilus microplus ticks during several months.

${ }^{+}$Corresponding author. E-mail: madruga@cnpgc.embrapa.br Received 19 May 2005

Accepted 6 September 2005
Potentially, outbreaks of babesiosis and anaplasmosis may occur if cattle is moved from humid areas to the semiarid regions during the short rainy season or inversely, if the cattle is transported from the semi-arid regions to humid regions, where tick prevalence is high. Interestingly, in some regions with very low seroprevalence of Babesia spp. the prevalence of $A$. marginale, determined by serological survey was high, suggesting other transmis-sion ways of infection than that by tick (Madruga et al. 1993).

There is a small number of studies regarding the epidemiological situation of babesiosis/anaplasmosis in the semi-arid regions of northestern states of Brazil. Despite the low population of cattle in these areas, this activity has an important social impact as subsistence for poor families.

One of the objectives of this work was to perform an epidemiological survey of Babesia spp. and A. marginale antibodies in cattle of semi-arid regions of Bahia, whose climate condition is common to large areas of other northeastern states.

In addition, indirect enzyme-linked immunosorbent assays (ELISA) with crude and recombinant antigens were evaluated for diagnostic of antibodies against $A$. marginale. In the last decades, ELISA has replaced indirect fluorescent antibody technique, because the former showed advantages such as possibility of analysis of a large number of tests in a shorter time and the discrimination of positive from negative sera without subjectivity (Madruga et al. 2000a). Various ELISA tests to detect antibodies against Babesia spp. and A. marginale with crude antigens were developed and evaluated in the last years (Molloy et al. 1998, Madruga et al. 2000a). More recently, efforts have 
been made to improve these serological tests for detection of antibodies against tick-borne diseases agents, especially $A$. marginale. One of these advances is the use of major surface protein-5 (MSP-5) as recombinant antigen (Knowles et al. 1996, Molloy et al. 1998, Reynna-Bello et al. 1998), although ELISA tests with A. marginale recombinant MSP1a and MSP2 antigens with high sensitivity and specificity have been recently described (Araújo et al. 2005 , in press). This protein is highly conserved among isolates of $A$. marginale and elicits a strong humoral response, which can be detected by serological tests for long periods (Knowles et al. 1996). However, until the present time, there were no comparative studies in epidemiological surveys between indirect ELISA tests with crude and recombinant antigens.

\section{MATERIALS AND METHODS}

Characterization of the studied areas - The serological survey was performed with sera from cattle raised in the dry polygon of Bahia (municipalities of Juazeiro, Senhor do Bonfim, Uauá, and Euclides da Cunha). Data concerning geographical location and climate of the municipalities are shown on Table I. This region is characterized by a small number of permanent rivers and the caatingas are the predominant vegetation (xenomorphic plants).

Sampling - The size of the cattle population studied was determined through a mathematical model developed by Pan American Zoonosis Center (1979) for epide-miological study of chronic diseases. The formula is the following: $\mathrm{n}=\mathrm{p}(100-\mathrm{p}) \mathrm{Z}^{2} /(\mathrm{d} . \mathrm{p} / 100)^{2}$, where $\mathrm{n}=$ sample number, $\mathrm{p}$ $=$ expected prevalence, $\mathrm{Z}=$ degree of con-fidence, and $\mathrm{d}=$ error margin. A pre-sampling was done with 50 sera from each county to estimate the expected prevalence. One hundred sixty five samples from each county was determined based on the lowest expected prevalence of seropositive animals for B. bovis, B. bigemina, or A. marginale. The minimal sampling confers $95 \%$ of confidence degree and $2 \%$ of error probability. Nevertheless, a higher number of sera was analyzed, 848 for Babesia and 823 for A. marginale prevalence study. The number of sampled animals by age group was the following for the Babesia survey: 112 cattle with 12-24 months old, 124 cattle 24 to 36 months of age, 91 bovines with 36 to 48 months of age, and 521 animals age over 48 months of age. For $A$. marginale were 98 animals for the group with 12-24 months of age and 510 for cattle over 48 months of age. The remaining age groups had animal number equal as above mentioned for Babesia spp. Ten milliliters of blood were collected from each animal from the jugular vein using vaccum tubes. The serum obtained was kept at $-20^{\circ} \mathrm{C}$ until the serological analysis in the laboratory of hemoparasite diagnosis at Embrapa Beef Cattle, was done.

Detection of antibodies against B. bovis and B. bigemi$n a$ - The indirect ELISA with crude antigen of $B$. bovis and $B$. bigemina were performed according to the techniques described by Madruga et al. (2000b, 2001), respectively.

Detection of antibodies against A. marginale - The crude ELISA antigen was performed according to Madruga et al. (2000a). The ELISA with recombinant MSP5 (rMSP5 ELISA), which is a stable GST fusion protein of the gene msp 5 cloned in the pGEX plasmid (Amersham Bioscience), was performed according to the protocol of the International Livestock Research Institute (Katende 1997). Briefly, the lyophilized antigen was reconstituted with glycerol and diluted in Dulbelcco's buffered phosphate solution (DBPS) for adsorption in 96 wells ELISA plates (F96 Polysorp Nunc-Immuno). In each well, 5.1

TABLE I

Geographical and climate data of Senhor do Bonfim, Euclides da Cunha, Uauá, and Juazeiro counties, Bahia, Brazil

\begin{tabular}{|c|c|c|c|c|}
\hline \multirow[b]{2}{*}{ Geographical and climate data } & \multirow[b]{2}{*}{ Senhor do Bonfim } & \multicolumn{3}{|c|}{ Counties } \\
\hline & & Euclides da Cunha & Uauá & Juazeiro \\
\hline South latitude & $10^{\circ} 27^{\prime}$ & $10^{\circ} 30^{\prime}$ & $09^{\circ} 50^{\prime}$ & $09^{\circ} 25^{\prime}$ \\
\hline West latitude & $40^{\circ} 11^{\prime}$ & $39^{\circ} 01^{\prime}$ & $39^{\circ} 29^{\prime}$ & $40^{\circ} 30^{\prime}$ \\
\hline Altitude (mt) & 550 & 450 & 439 & 371 \\
\hline \multicolumn{5}{|l|}{ Temperature $\left({ }^{\circ} \mathrm{C}\right)$} \\
\hline Minimum & 19,2 & 19,7 & 20,0 & 20,3 \\
\hline Average & 23,3 & 23,6 & 23,9 & 24,2 \\
\hline Maximum & 28,3 & 28,6 & 28,9 & 29,6 \\
\hline \multicolumn{5}{|l|}{ Annual precipitation (mm) } \\
\hline Minimum & 391 & 263 & 29 & 98 \\
\hline Average & 843 & 718 & 495 & 427 \\
\hline Maximum & 1567 & 1442 & 1613 & 1055 \\
\hline Climate type & Semi-arid dry & $\begin{array}{c}\text { Semi-arid } \\
\text { and sub-humid }\end{array}$ & $\begin{array}{l}\text { Semi-arid } \\
\text { and arid }\end{array}$ & $\begin{array}{l}\text { Semi-arid } \\
\text { and arid }\end{array}$ \\
\hline Rainy season & February to April & May to July & February to April & January to March \\
\hline
\end{tabular}

Source: Centro de Estatística e Informação (1994a,b) 
$\mu \mathrm{g}$ of the diluted antigen were added and adsorption was performed during $90 \mathrm{~min}$ at $37^{\circ} \mathrm{C}$. Blocking of the wells was done with DBPS containing $0.2 \%$ of casein (DBPS-C) for $20 \mathrm{~min}$ at $37^{\circ} \mathrm{C}$. Control and test sera were diluted 1:50 in dilution buffer (DBPS plus 2\% of skim milk) and incubated at $37^{\circ} \mathrm{C}$ for $45 \mathrm{~min}$. After three washes with DBPS containing $0.1 \%$ of tween-20 (DBPS-T), anti-bovine IgG peroxidase conjugate (Sigma A-7414) diluted 1:24,000 in DBPS containing $0.2 \%$ casein and $0.1 \%$ Tween-20 (DBPS$\mathrm{C}-\mathrm{T}$ ) was added in each well and incubated at $37^{\circ} \mathrm{C}$ for 30 min. The substrate $\mathrm{H}_{2} \mathrm{O}_{2}$ and chromogen 2,2'-azino-di [3-ethilbenzithianzoline-acid sulphonate(6)] solution were added and the results were read in a spectrophotometer (Bio-Tek Elx 800) with a 414 ๆm filter after $30 \mathrm{~min}$.

In all Babesia spp. ELISA tests, the strong and weak positive control sera were obtained from calves free of haemoparasitic infections determined by indirect immunofluorescent antibody technique which were inoculated experimentally with $5 \times 10^{6} \mathrm{~B}$. bovis and $\mathrm{B}$. bigemina organisms. The $A$. marginale sera controls used were the same employed in the development and evaluation of the ELISA test in the ILRI, Nairobi, Kenya.

Statistical analysis - The prevalences of B. bovis, B. bigemina, and $A$. marginale antibodies in the semi-arid micro-regions and in each county were statistically analyzed employing chi square as provided by the INSTAT 2 program (GraphPad Inc). The comparison of I-ELISACrAnaAg and I-ELISA-MSP-5Ag was done using the t-student test with $95 \%$ degree of confidence.

\section{RESULTS}

The overall prevalence of $B$. bovis and B. bigemina determined by antibody detection in cattle from the semiarid of Bahia were 77.7 and $75.5 \%$, respectively. The prevalence of $A$. marginale antibodies in this region was 98.9 and $97 \%$, respectively by I-ELISA-CrAnaAg and IELISA-MSP-5Ag. The prevalence of seropositive animals ranged from 56.4 to $95.5 \%$ to B. bovis and from 53 to $91.3 \%$ to $B$. bigemina (Fig. 1) and were significantly higher in Senhor do Bonfim and Euclides da Cunha counties (P $\leq 0.05)$. The prevalence of $A$. marginale determined by crude antigen and rMSP5 ELISA tests are shown in Fig. 2. No significant statistical differences were observed in the prevalence of this rickettsia among the studied municipalities of Bahia ( $\mathrm{P} \geq 0.05)$. The comparison between crude antigen and rMSP5 ELISAs (Table II) showed a highly significant association of results $(r=0.98)$. Despite the variation in the number of cattle sampled by age group, the differences in the prevalence of $B$. bovis, B. bigemina
(Table III), and A. marginale (Fig. 3) between age groups and from the mean prevalence in the four counties of the semi-arid region groups were not significant $(\mathrm{P}>0.05)$.

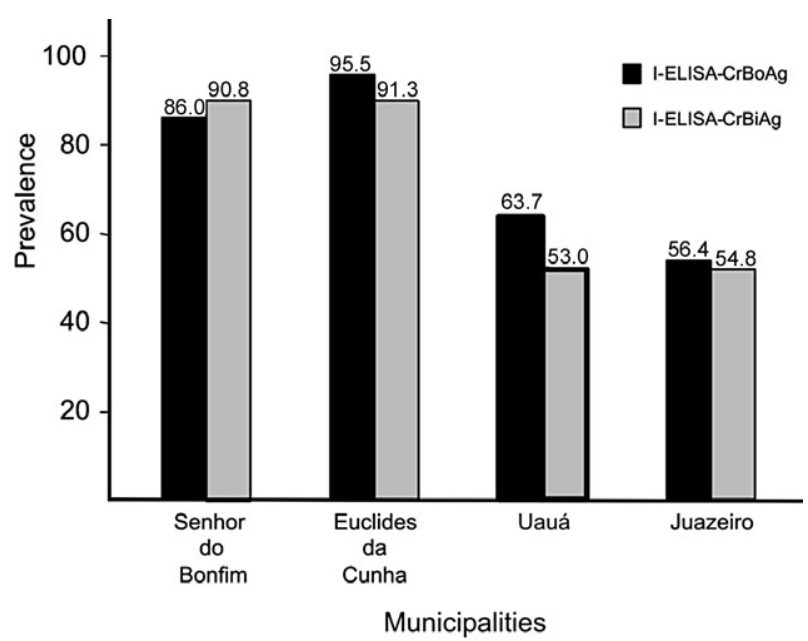

Fig. 1: prevalence of Babesia bovis and Babesia bigemina antibodies determined by enzyme-linked immunosorbent assays with crude antigens of the prior hemoparasite (I-ELISA-CrBoAg) and later one (I-ELISA-CrBiAg), in four counties of the semi-arid region of the state of Bahia, Brazil.

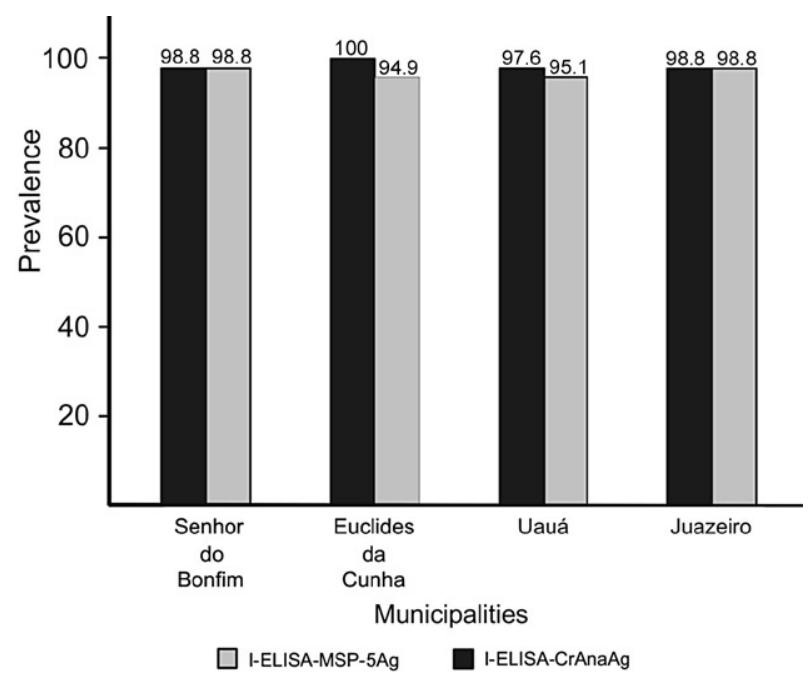

Fig. 2: prevalence of Anaplasma marginale antibodies in cattle of four municipalities of the semi-arid region of the state of Bahia, Brazil, by indirect enzyme-linked immunosorbent assays with crude antigen (I-ELISA-CrAnaAg) and recombinant major surface protein 5 (I-ELISA-MSP-5Ag).

TABLE II

Correlation between enzyme-linked immunosorbent assay (ELISA) with crude antigen (I-ELISA-CrAnaAg) and with recombinant major surface protein-5 (I-ELISA-MSP-5Ag) in detecting antibodies against Anaplasma marginale in cattle from the semi-arid region of the state of Bahia, Brazil

\begin{tabular}{lccc}
\hline & I-ELISA-CrAnaAg + & I-ELISA-CrAnaAg - & Total \\
\hline I-ELISA-MSP-5Ag + & 800 & 0 & 800 \\
I-ELISA-MSP-5 - & 16 & 9 & 25 \\
\hline Total & 816 & 9 & 825 \\
\hline
\end{tabular}


TABLE III

Frequency of Babesia bovis and Babesia bigemina antibodies by age group in cattle from the semi-arid region of he state of Bahia, Brazil

\begin{tabular}{cccc}
\hline & \multicolumn{2}{c}{ Frequency } & \\
\cline { 2 - 3 } Age group & B. bovis & B. bigemina & Total number \\
\hline $12-\mid 24$ & 78.6 & 75.0 & 112 \\
$24-36$ & 79.9 & 75.8 & 124 \\
$36-48$ & 79.1 & 78.8 & 91 \\
$\geq 48$ & 76.8 & 75.4 & 521 \\
\hline Total & 77.7 & 75.5 & 84 \\
\hline
\end{tabular}

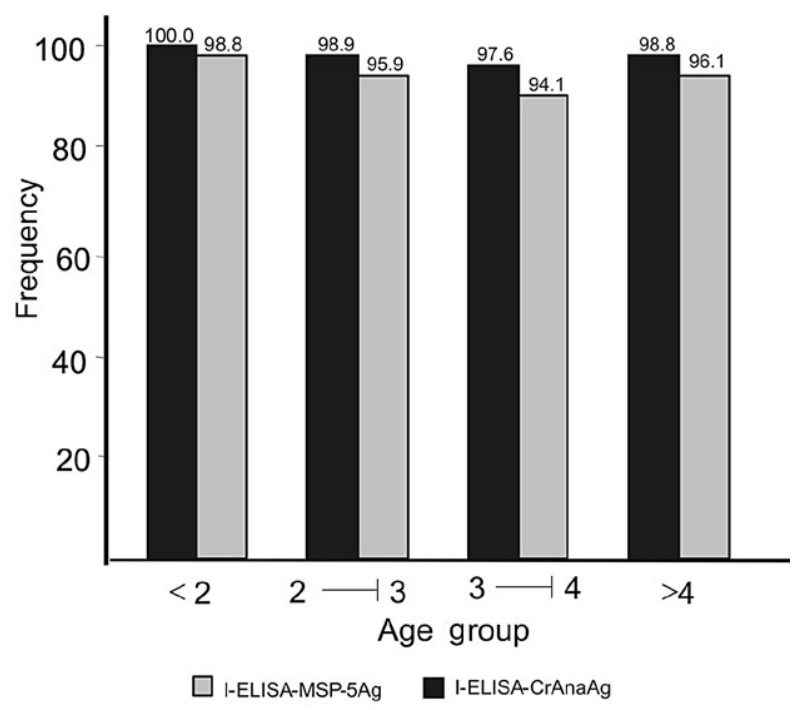

Fig. 3: frequency of Anaplasma marginale seropositive animals by age group by indirect enzyme-linked immunosorbent assays with crude antigen (I-ELISA-CrAnaAg) and recombinant major surface protein 5 (I-ELISA-MSP-5 Ag) in four municipalities of the semi-arid region of the state of Bahia, Brazil.

\section{DISCUSSION}

The results showed two distinct epidemiological conditions in the semi-arid region of Bahia. Senhor do Bonfim, and Euclides da Cunha counties were characterized as enzootically stable areas for B. bovis and B. bigemina, while Uauá and Juazeiro were described as unstable, according to the mathematical model developed by Mahoney (1975). On the other hand, applying the same model, the prevalence of $A$. marginale antibodies, characterized all four counties of this region as enzootically stable. The epidemiological distinction among the mentioned counties for both Babesia sp. seems to be associated with the interaction of climate and the life cycle of the only vector of these hemoprotozoans.

Temperature and humidity are well known as crucial factors for B. microplus development and the latter climate factor seems to be determinant for the distinct epidemiological conditions found in the semi-arid region of Bahia. Although the rainy season in all four counties lasted three months, the mean annual pluviometric precipitation was above $700 \mathrm{~mm}$ in those with enzootic stability, while in the unstable the mean annual pluviometric precipitation was under $500 \mathrm{~mm}$. The prevalence of B. bovis and $B$. bigemina antibodies in Senhor do Bonfim and Euclides da Cunha were similar to that found for B. bovis, $96.6 \%$, in the southern region of Bahia, where the temperature and humidity are favorable to the tick biological cycle (Araújo et al. 1998). These results are also similar to those in other Brazilian states where $B$. microplus has conditions to complete its biological cycle during all year (Madruga et al. 2000a, Soares et al. 2000). Similarly to Uauá and Juazeiro, a low percentage of antibodies against Babesia spp. was found in the semi-arid region of Cariri in the state of Paraíba, characterizing an enzootic unstable area (Ma-druga et al. 1993).

The enzootic stability of $A$. marginale in the semiarid municipalities, including Uauá and Juazeiro, is an indication that the transmission of this rickettsia is not only dependent of $B$. microplus population. Similar epi-demiological situation was found in the semi-arid region of Cariri, in Paraíba. However in a region with the same climate characteristics, in the state of Sergipe, the $A$. marginale prevalence was only $16.3 \%$ (Oliveira et al. 1992). The description of anaplasmosis outbreaks in areas where tick B. microplus was eradicated (Gugliemone $1995)$ supports that other factors play important role in the epidemiology of $A$. marginale.

Tabanids have been implicated as mechanical vectors of $A$. marginale for a long time. Recently in an epidemiological study of $A$. marginale in Bolivia, it was concluded that tabanids were responsible for the elevated prevalence of this rickettsia in that country (Carique et al. 2000). However, the humidity of the semi-arid region is not favorable for the development of tabanids, like it is not for the ixodidae, except during the short rainy season. Probably the most important epidemiological factor for the establishment of high prevalence is the persistence of $A$. marginale infection in the reservoir. Consequently, the needles used in the vaccinations and contaminated surgical instruments make the iatrogenic transmission an efficient way of infection spreading (Brinkman \& Kersting 1990). The long persistence of $A$. marginale infection in cattle and the intrauterine transmission even by cow raised in area free of $B$. microplus tick (Bock et al. 2003) may be important factors for $A$. marginale epidemiology, albeit this way of infection is not considered epi-demiologically important due to the low frequency, according to Ribeiro et al. (1996).

Despite the reduced population of $B$. microplus in some areas of Bahia semi-arid region, $A$. marginale infection occurs in early age of the animals because the frequency of seropositive animals was above $98 \%$ in both ELISA tests in cattle with less than two years of age.

Therefore, we concluded that there is risk of babesiosis outbreaks, but not of anaplasmosis, in cattle raised in Uauá and Juazeiro.

Although the higher number of seropositive animals in the crude antigen ELISA, it was not statistically significant and possibly it was due to the greater polyantigenicity of the crude antigen compared with recombinant MSP-5. 
Also it is possible that non-specific reactions in the crude antigen ELISA, due to antibodies against red blood cells contaminants, influenced this difference, but according to previous evaluation, this is negligible (Madruga et al. 2000a). The indirect rMSP-5 ELISA has the advantage over the competitive ELISA that uses recombinant MSP-5 as antigen due to the lesser complexity and shorter time of execution. Therefore, both ELISA tests employed in this investigation proved to be useful for serological surveys of epidemiological studies and as evaluation tools in deciding the preventive measures to be used.

\section{REFERENCES}

Araújo FR, Madruga CR, Leal CRB, Bastos PAS, Marques APC 1998. Freqüência de anticorpos anti-Anaplasma marginale em rebanhos leiteiros da Bahia. Arq Bras Med Vet Zootec 50: $243-246$

Araújo FR, Melo VSP, Ramos CAN, Madruga CR, Soares CO, Kessler RH, Almeida NF, Araújo GS, Alves LC, Torres Junor, RAA, Fragoso SP, Arauco PRC, Bacanelli G, Oliveira MB, Santos LR 2005. Development of enzyme im-munosorbent assays based on recombinant MSP1a and MSP2 of Anaplasma marginale. Mem Inst Oswaldo Cruz 100: in press.

Bock RE, de Vos AJ, Kingston TG, Carter PD 2003. Assessment of a low virulence Australian isolate of Anaplasma marginale for pathogenicity and transmissibility by Boophilus microplus. Vet Parasitol 118: 121-131.

Brinkman MH, Kersting KW 1990. Bovine anaplasmosis: an overview. Iowa State University Veterinarian 52: 34-38.

Carique Mas JJ, Widdowson MA, Cuellar AM, Ribeira H, Walker AR 2000. Risk of babesiosis and anaplasmosis in different ecological zones of Santa Cruz Department, Bolivia. Vet Parasitol 93: 29-38.

Centro de Estatística e Informações 1994a. Informações Básicas dos Municípios Baianos, Piemonte da Diamantina, Salvador, $517 \mathrm{pp}$.

Centro de Estatística e Informações 1994b. Informações Básicas dos Municípios Baianos, Nordeste vol. I (Euclides da Cunha) e vol. II (Uauá) Salvador, 955 pp.

Centro Pan-Americano de Zoonosis 1979. Procedimientos para estudios de prevalencia por muestreo. Ramos Mejia, Buenos Aires. Nota Técnica 18, 35 pp.

Grisi L, Massard CL, Borja GEM, Pereira JB 2002. Impacto econômico das principais ectoparasitoses em bovinos no Brasil. Hora Veterinária 21: 8-10.

Gugliemone AA 1995. Epidemiology of babesiosis and anaplasmosis in South and Central America. Vet Parasitol 57: 109-119.

Katende JM 1997. An indirect ELISA for antibody detection for Anaplasma marginale in bovine serum: Protocol. International Livestock Research Institute, Nairobi, Kenya, $24 \mathrm{pp}$.

Kessler RH, Schenk MAM 1998. Tristeza parasitária dos bovinos (TPB): conceito, etiologia, transmissão, epide-miologia, diagnóstico e controle. In RH Kessler, MAM Schenk (eds), Carrapato, Tristeza Parasitária e Tripanos-somose dos bovinos, Embrapa, Campo Grande, p. 48-67.
Knowles D, de Echaide ST, Palmer G, McGuire T, Stiller D, McElwain T 1996. Antibody against an Anaplasma marginale MSP5 epitope common to tick and erithrocyte stages identifies persistently infected cattle. J Clin Micro-biol 34: 2225-2230

Madruga CR, Araújo FR, Marques APC, Carvalho CME, Cusinato EQ, Crocci AJ, Kessler RH, Miguita M 2000b. Desenvolvimento de uma prova de imunoadsorção enzimática para detecção de anticorpos contra Babesia bovis. Pesq Vet Bras 20: 167-170.

Madruga CR, Honer MR, Andreotti MR, Araújo FR, Santarém V 1993. Prevalência de Anaplasma marginale em três regiões do estado da Paraíba. In Congresso Internacional de Medicina Veterinária em Língua Portuguesa, 6, Anais, p. 350-352.

Madruga CR, Marques APC, Leal CRB, Carvalho CME, Araújo FR, Kessler RH 2000a. Evaluation of an enzyme-linked immunosorbent assay to detection antibodies against Anaplasma marginale. Pesq Vet Bras 20: 109-112.

Madruga CR, Marques APC, Araujo FR, Miguita M, Carvalho CME, Araújo ES, Umaki ACS, Crocci AJ, Queiroz RA 2001. Evaluation of an ELISA for detection of antibodies to Babesia bigemina in cattle and its application in an epidemiological survey in Brazil. Pesq Vet Bras 21: 72-76.

Mahoney DF 1975. The diagnosis of babesiosis in Australia. In EA Wells, Workshop on Hemoparasites (Anaplasmosis and Babesiosis). CIAT, Cali, Colombia.

Molloy JB, Bowles PM, Jeston PJ, Bruyeres PG, Bowden JM, Bock RE, Jorgensen WK, Blight GW, Dalgliesh RJ 1998. Development of an enzyme-linked immunosorbent assay for detection of antibodies to Babesia bigemina cattle. Parasitol Res 84: 651-656.

Oliveira AA, de Pedreira PAS, Almeida MFR 1992. Doenças de bezerro. II Epidemiologia da anaplasmose no estado de Sergipe. Arq Bras Med Vet Zootec 44: 377-386.

Quintão-Silva MG, Ribeiro MFB 2003. Infection rate of Babesia spp. sporokinetes in engorged Boophilus microplus from area of enzootic stability in the state of Minas Gerais, Brazil. Mem Inst Oswaldo Cruz 98: 999-1002.

Reeves JD, Swift BL 1977. Iatrogenic transmission of Anaplasma marginale in beef cattle. Vet Med Small Anim Clin 13: 911-914

Ribeiro MFB, Lima JD, Salcedo JHP 1996. Attempted transmission of Anaplasma marginale by infected Boophilus microplus. Arq Bras Med Vet Zootec 48: 397-402.

Reyna-Bello A, Cloeckart A, Vizcaino N, Gonzatti MI, Aso PM, Dubray G, Zygmunt M 1998. Evaluation of an enzyme-linked immunosorbent assay using recombinant major surface protein 5 (MSP-5) for serologic diagnosis of bovine anaplasmosis in Venezuela. Clin Diagn Lab Immunol 5: 259-262.

Soares CO, Souza JC, Madruga CR, Madureira RC, Massard CL, Fonseca AH 2000. Soroprevalência de Babesia bovis em bovinos da mesoregião Norte Fluminense. Pesq Vet Bras 20: 75-79.

Souza JCP, Soares CO, Massard CL, Scofield A, Fonseca AH 2000. Soroprevalência de Anaplasma marginale em bovinos na mesorregião Norte Fluminense. Pesq Vet Bras 20: 97-101. 